DOI: $10.35619 /$ iiu.v1i10.195

Пріма Дмитро

кандидат педагогічних наук, старший викладач кафедри соціальної роботи і педагогіки вищої школи Східноєвропейського національного університету імені Лесі Українки, м. Луцьк, Україна

ORCID: 0000-0002-2102-9932 e-mail:primar@ukr.net

\title{
ГРОМАДЯНСЬКІСТЬ ЯК ІНТЕГРАТИВНА ЯКІСТЬ ОСОБИСТОСТІ МАЙБУТНЬОГО ФАХІВЦЯ
}

Анотація. Метою статті $є$ аналіз змістових аспектів поняття «громадянськість» як інтегративної особистісної якості майбутнього фахівця, складової його громадянської професійної позиції. У контексті розкриття термінологічного поля окресленої проблеми проаналізовано дефініції поняття «громадянськість» як категорії соціології, політології, психології, педагогіки. Узагальнено, що громадянськість є соціальнопсихологічним поняттям, позаяк у ньому фіксується психолого-етичний зв'язок особистості з державою, а як складне ціннісно-емоційне утворення спонукає до участі у громадянському житті. Наголошено, що громадянськість $є$ якістю особистості, яка не надається людині формально, а виховується в ній і розглядається як кінцевий результат іiі громадянського виховання. Увагу закцентовано на характеристиці громадянськості як цілісного особистісного утворення; як зовнішньої та внутрішньої сторони структури особистості, взаємозв'язаних і взаємозумовлених, що посилює внутрішню сутність громадянськості, актуалізує прояв громадянської позиції. Зроблено висновок, що громадянськість $\epsilon$ інтегративним у змістовому сенсі поняттям, а підготовка майбутнього фахівця для будь-якої професійної галузі має забезпечити формування в ньому громадянськості, наявність якої дозволяє стверджувати про сформованість в особистості громадянської позиції й готовності до її прояву.

Ключові слова: громадянин, громадянське виховання, громадянськість, громадянська позиція, особистість, цілісне особистісне утворення.

Постановка проблеми. В умовах активної демократизації держави, відстоювання своєї цілісності прагнення суверенної України стати повноправним членом європейської спільноти спричинює посилення ролі громадянського виховання молоді як «соціально активних, національно свідомих, патріотично налаштованих громадян, із високим почуттям громадянськості та глибокою громадянською відповідальністю» (Ївженко, 2017, с. 19), що дотримується демократичних цінностей та настанов у своїй поведінці. На важливості громадянського виховання наголошується у Концепції громадянського виховання особистості в умовах розвитку української державності, де відзначається, що «громадянське виховання - це процес формування громадянськості як інтегрованої якості особистості, що надає людині можливість відчувати себе морально, соціально, політично та юридично дієздатною та захищеною. Воно покликане виховувати особистість чутливою до свого оточення, залучати іiі до суспільного життя, в якому права людини є визначальними» (Концепція, 2001, с. 7). Попри те, що тлумачення цього поняття, як слушно зауважує Т. Кравченко (Кравченко, 2018), дещо звужує можливості громадського виховання (ми погоджуємося з цією думкою), воно орієнтує, передусім, на розвиток громадянськості. Отже, актуалізується освітня складова громадянського виховання майбутнього фахівця, нерозривно пов'язана $з$ усвідомленням особистістю своєї національної 
приналежності, орієнтацією на активну громадську діяльність, засвоєнням нею системи моральних та громадянських цінностей.

Аналіз останніх досліджень 3 проблеми. Аналіз наукової літератури засвідчив різноплановість студіювання проблеми громадянського виховання майбутніх фахівців, a саме: історико-педагогічні аспекти (Т. Завгородня, П. Ігнатенко, І. Кучинська, О. Рацул та інші); зміст, методи і форми громадянського виховання та формування громадянської позиції (І. Бех, Ю. Залевський, М. Михайліченко, Н. Косарєва, Л. Омельченко, О. Пометун, В.Поплужний та інші); особливості громадянського виховання студентської молоді (Т. Дем'янюк, М. Євтух, В. Іванчук, Г. Шевченко та інші); формування системи громадянських цінностей (Н. Калініченко, Л. Корінна, Б. Ступарик, О. Сухомлинська та інші); наукові підходи до формування громадянської компетентності (І. Бойко, С. Бондар, В. Вербицька, О. Кучер, С. Позняк та інші); виховання громадянськості студентів (Т. Гребеник, Ю. Завалевський, О. Сухомлинська та ін.).

Мета статті: проаналізувати змістові аспекти поняття «громадянськість» як інтегративної особистісної якості майбутнього фахівця, складової його громадянської професійної позиції.

Виклад основного матеріалу дослідження. Дослідження термінологічного поля окресленої проблеми показало, що поняття «громадянськість» веде свій початок із суспільних наук. Так, у соціології громадянськість характеризується як «сукупність правил і ресурсів, які сприяють виробництву чи відтворенню соціальних інститутів, зафіксованих у часі та просторі» (Гидденс, 2005, с. 68).

За Політичним словником «громадянськість - це спрямованість на користь суспільства, підпорядкування особистих інтересів громадянським, служіння Батьківщині; дотримання правил і виконання обов'язків, встановлених законами держави» (Політичний енциклопедичний словник, 1997, с. 27).

Суттєво, що у політичних науках цей феномен розглядається як антитеза аполітичності, активна і свідома включеність у справи політичного співтовариства; психологічне відчуття себе громадянином, повноправним у політичному співтоваристві; здатність і готовність виступати в ролі громадянина; вища чеснота вільного і повноправного учасника політичного співтовариства; прихильність до інтересів політичного співтовариства, готовність іти на жертви заради цих інтересів (Политология: Энциклопедический словарь, 1993, с. 78).

За Великим тлумачним словником сучасної української мови та Українським педагогічним словником поняття «громадянськість» трактується як «усвідомлення кожним громадянином своїх прав та обов'язків щодо держави та суспільства, почуття відповідальності за їхнє становище» (Великий тлумачний словник сучасної української мови, 2007, с. 262; Український педагогічний словник, 1997, с. 75).

Уважаємо конструктивною думку В. Ядова (Ядов, 1975), в якій стверджується, що громадянськість висвітлює певний зв'язок між конкретним громадянином держави й особистістю як суб'єктом суспільних відносин i діяльності. При цьому громадянськість синтезує в собі цінності й норми суспільства, стає запорукою активності, ініціативності особистості в іiі власному внеску в розвиток держави, оскільки саме завдяки сформованості громадянськості людина може усвідомити свою роль у суспільстві, відчути повноту любові до Батьківщини та відповідальності за ії майбутнє. Вочевидь, поняття «громадянськість» соціально-психологічне, позаяк у ньому фіксується психолого-етичний зв'язок особистості з державою.

Л. Снігур (Снігур, 2005), досліджуючи психологічні аспекти становлення громадянськості особистості, зауважує, що основою розвитку громадянськості $\epsilon$ особливе ставлення особистості до свого народу та прав і обов'язків громадянина. При цьому усвідомлення зв'язку з власним родом та народом створює складне ціннісноемоційне утворення, що спонукає до участі у громадянському житті. 
Громадянськість, наголошує Н. Волкова (Волкова, 2007), не лише зумовлює духовно-моральну цінність громадянина, але й пов'язана зі світоглядною й психологічною характеристикою особистості, позаяк саме ця якість визначає обов'язок і відповідальність особистості перед співвітчизниками, Батьківщиною. Отже, цілком правомірно стверджувати, що громадянськість відповідає такому рівню особистісного саморегулювання, коли метою поведінки людини $є$ свідома діяльність заради країни.

Відзначимо, що громадянськість - якість, яка не надається людині формально, а виховується в ній. Ця думка підтверджується у визначеннях провідних вітчизняних науковців. Так, О. Вишневський, розглядаючи «громадянськість» як кінцевий результат громадянського виховання особистості, виокремив основні громадянські якості та їх показники, які мають бути притаманні будь-якій особистості, а саме: пошана до законів та рівність громадян перед законом, відстоювання прав людини на життя, власну гідність, безпеку життя, приватну власність, рівність можливостей, самовідповідальність людини тощо (Вишневський, 1996).

Громадянськість характеризується Л. Пархоменко (Пархоменко, 2008) як цілісне особистісне утворення, що складається 3 особистісних якостей, найважливішими 3 яких, на думку дослідниці, є: громадянська самосвідомість, почуття громадянської гідності, почуття громадянського обов'язку, почуття громадянської відповідальності, громадянська совість, громадянська мужність.

Заслуговує на увагу авторське бачення громадянськості, запропоноване Ю. Залевським (Залевський, 2003), згідно 3 яким громадянськість характеризується як зовнішня i внутрішня сторони структури особистості, які не просто взаємопов'язані, а є продовженням одна одної, оскільки внутрішня суть громадянськості особистості спонукає до прояву громадянських якостей у зовнішній формі: вчинках, діяльності, взаємовідносинах, а зовнішня форма прояву посилює внутрішню сутність громадянськості, актуалізує прояв громадянської позиції чи закріплює іiі.

Висновки i перспективи подальших розвідок. Отже, в контексті вищевикладеного цілком правомірно стверджувати, що громадянськість $\epsilon$ інтегративним у змістовому сенсі поняттям, яке виражається : в усвідомленні й оцінці особистістю свого положення в суспільстві, державі, своїх прав і обов'язків громадянина; у сукупності громадянських почуттів і якостей, за допомогою яких особистість має змогу зміцнити своє положення громадянина в суспільстві, спроможна свідомо діяти;в актуалізації прояву громадянської позиції особистості майбутнього фахівця чи закріпленні іiі.

Ми солідарні $з$ думкою Н. Савотіної (Савотина, 2002), що підготовка майбутнього фахівця для будь-якої професійної галузі має забезпечити формування в ньому громадянськості. Водночас наявність громадянськості дозволяє стверджувати про сформованість в особистості громадянської позиції й готовності до ії прояву. Перспективи подальших розвідок пов'язуємо з дослідженням теоретико-методичних підходів щодо формування громадянської позиції майбутнього педагога, зокрема вчителя початкової школи.

\section{СПИСОК ВИКОРИСТАНИХ ДЖЕРЕЛ}

Ївженко, Ю. (2017). Формування у студентської молоді почуття громадянськості в молодіжних громадських організаціях. Кандидат педагогічних наук. Східноукраїнський національний університет імені Володимира Даля, Київ.

Концепція громадянського виховання особистості в умовах розвитку украӥнської державності (2001). Шлях освіти.

Кравченко, Т. (2018). Громадянське виховання у працях українських та британських учених. [online]. Режим доступу: http://www.kamts1.kpi.ua/ sites/default/files/files/kravchenko_gromadianske.pdf [Дата останнього звернення 10 жовтня 2019]. 
Гидденс, Э.(2005). Устроение общества: Очерк теории структуризации. 2-е изд. Москва: Академический Проект.

Политология: Энциклопедический словарь. (1993). Общ. ред. и сост. Ю. И. Аверьянова. Москва: Московский коммерческий университет.

Політичний енциклопедичний словник: навч. посіб. для студ. вищих навч. закл. (1997). Київ : Генеза, 278 с.

Великий тлумачний словник сучасної украӥнської мови (2007). Уклад. і гол. ред. В. Т. Бусел. Київ-Ірпінь.

Український педагогічний словник (1997). Укл. С. У. Гончаренко. Київ: Либідь. $376 \mathrm{c}$.

Ядов, В. (1975). Про диспозииійні регуляиії соиіальної поведінки особистості. Методологічні проблеми соціальної психології. М.: Наука/ С. 89-105.

Снігур, Л. (2005). Психологія становлення громадянськості особистості: автореф. Доктор психологічних наук. Інститут психології ім. Г.С.Костюка АПН України. Київ.

Волкова, Н. (2007). Педагогіка: посібник. Вид. 2-е, переробл. Київ: Академвидав. $616 \mathrm{c}$.

Вишневський, О. (1996). Сучасне украӥнське виховання : педагогічні нариси. Львів.

Пархоменко, Л. (2008). Громадянське виховання: теорія та досвід. Виховна робота в школі. № 4 (41) квітень, с. 2-22.

Завалевський, Ю. (2003). Деякі аспекти формування громадянської спрямованості старшокласників у процесі виховної діяльності. Педагогіка. № 3, с. 12-14.

Савотина, Н. (2002) Гражданское воспитание : традиции и современные требования. Педагогика. № 4. С. 39-42.

\section{REFERENCES}

Yivzhenko, Yu. (2017). Formuvannia u studentskoi molodi pochuttia hromadianskosti v molodizhnykh hromadskykh orhanizatsiiakh [Formation of a Sense of Citizenship Among Students in Youth Public Organizations]. Kandydat pedahohichnykh nauk. Skhidnoukrainskyi natsionalnyi universytet imeni Volodymyra Dalia, Kyiv. (in Ukrainian)

Kontseptsiia hromadianskoho vykhovannia osobystosti $v$ umovakh rozvytku ukrainskoi derzhavnosti (2001) [The Concept of Civic Education of the Individual in the Conditions of Development of the Ukrainian Statehood (2001)]. Shliakh osvity. (in Ukrainian)

Kravchenko, T. (2018). Hromadianske vykhovannia u pratsiakh ukrainskykh ta brytanskykh uchenykh. [Civic Education in the Works of Ukrainian and British scholars] [online]. Rezhym dostupu :http://www.kamts1.kpi.ua/sites/default/files/files/kravchenko_gromadianske.pdf [Data ostannoho zvernennia 10 zhovtnia 2019] (in Ukrainian)

Giddens, E. (2005). Ustroeniye obschestva: Ocherk teorii strukturatsyi [Organization of Society: Essay on the Theory of Structure]. 2-e izd. Moskva: Akademicheskiy Proekt. (in Russian)

Politologiya: Entsiklopedicheskiy slovar. (1993). [Political Science: Encyclopedic Dictionary] Obsch. red. i sost. Yu. I. Averyanova. Moskva: Moskovskiy kommercheskiy universitet. (in Russian)

Politychnyi entsyklopedychnyi slovnyk [Political Encyclopedic Dictionary]: navch. posib. dlia stud. vyshchykh navch. zakl. (1997). Kyiv : Heneza, 278 s. (in Ukrainian)

Velykyi tlumachnyi slovnyk suchasnoi ukrainskoi movy. (2007). [Great Explanatory Dictionary of the Modern Ukrainian Language]. Uklad. i hol. red. V. T. Busel. Kyiv-Irpin. (in Ukrainian)

Ukrainskyi pedahohichnyi slovnyk (1997). [Ukrainian Pedagogical Dictionary]. Ukl. S. U. Honcharenko. Kyiv: Lybid. 376 s. (in Ukrainian)

Yadov, V. (1975). Pro dyspozytsiini rehuliatsii sotsialnoi povedinky osobystosti [On Dispositional Regulation of Social Behavior of the Individual]. Metodolohichni problemy sotsialnoi psykholohii. Moskva: Nauka, s.89-105. (in Ukrainian) 
Snihur, L. (2005). Psykholohiia stanovlennia hromadianskosti osobystosti: [Psychology of Formation of a Citizenship of Personality]. Doktor psykholohichnykh nauk. Instytut psykholohii im. H.S.Kostiuka APN Ukrainy. Kyiv. (in Ukrainian)

Volkova, N. (2007). Pedahohika: posibnyk [Pedagogy: a textbook]. Vyd. 2-e, pererobl. Kyiv: Akademvydav. 616 s. (in Ukrainian)

Vyshnevskyi, O. (1996). Suchasne ukrainske vykhovannia : pedahohichni narysy [Contemporary Ukrainian Education: Pedagogical Essays]. Lviv. (in Ukrainian)

Parkhomenko, L. (2008). Hromadianske vykhovannia: teoriia ta dosvid [Civic Education: Theory and Experience]. Vykhovna robota v shkoli. No4 (41) kviten, s. 2-22. (in Ukrainian)

Zavalevskyi, Yu. (2003). Deiaki aspekty formuvannia hromadianskoi spriamovanosti starshoklasnykiv u protsesi vykhovnoi diialnosti [Some Aspects of Formation of the Civic Orientation in High School Students in the Educational Process]. Pedahohika. No 3, s. 12-14. (in Ukrainian)

Savotina, N. (2002) Grazhdanskoe vospitanie : traditsii i sovremennyye trebovaniya. [Civic Education: Traditions and Modern Requirements]. Pedagogika. No 4, s. 39-42. (in Russian)

\title{
CIVILIANS AS AN INTEGRATIVE QUALITY OF THE PERSONALITY OF THE FUTURE SPECIALIST
}

\author{
Dmytro Prima \\ Candidate of Pedagogical Sciences, \\ Senior Lecturer at the Department of Social Work and Pedagogy of the Higher School, \\ Lesya Ukrainka Eastern European National University, \\ Lutsk, Ukraine \\ ORCID: 0000-0002-2102-9932 \\ e-mail:primar@ukr.net
}

\begin{abstract}
The purpose of the article is to analyze the substantive aspects of the concept of "citizenship" as an integrative personal quality of a future specialist, a component of his civic professional position. In the context of exposing the terminological field of the outlined problem, the definitions of the concept of "citizenship" as a category of sociology, political science, psychology, pedagogy has been analyzed. Generally speaking, citizenship is a sociopsychological concept, because it captures the psychological and ethical connection of the individual with the state, and as a complex value-emotional formation leads to participation in civic life. It is emphasized that citizenship is a quality of personality, which is not given to a person formally, but it is brought up in him and is considered as the final result of his civic education. It focuses on the characterization of citizenship as a whole personal formation, consisting of personal qualities, the most important of which are: civic self-awareness, sense of civic dignity, sense of civic responsibility, civic conscience, civic courage; as external and internal to the structure of personality, interconnected and interdependent, which reinforces the inner essence of citizenship, actualizes the manifestation of civic position. It is concluded that citizenship is an integrative in the sense of the term, which is expressed in the awareness and assessment of the personality of his position in society, the state, her rights and responsibilities of the citizen, in the aggregate of civic feelings and qualities, through which the person is able to strengthen their position of a citizen in society, capable of consciously acting, actualizing the manifestation of the civic position of a person of a future specialist or securing him, and the preparation of a future specialist for any professional field has to ensure the formation of citizenship in it, the presence of which allows to confirm the formation of a civic position in the personality and readiness for its manifestation.
\end{abstract}

Keywords: citizen, civic education, citizenship, civic position, personality, holistic personal formation.

Стаття надійшла до редакиії 08.10.2019 р 